\title{
An Analysis of Dee's Identity Construction from the Perspective of Consumer Culture
}

\author{
Qian Zhang1, Haimei Liu ${ }^{2}$ \\ ${ }^{1}$ Foreign Language Department, Baoding University, Baoding, China \\ ${ }^{2}$ School of Foreign Languages and Literature, Yan Shan University, Qinhuangdao, China \\ Email: zq757602@163.com
}

Received 2 May 2014; revised 5 June 2014; accepted 1 July 2014

Copyright (C) 2014 by authors and Scientific Research Publishing Inc.

This work is licensed under the Creative Commons Attribution International License (CC BY). http://creativecommons.org/licenses/by/4.0/

(c) (†) Open Access

\section{Abstract}

This paper will focus on the role of the consumer culture in Dee's identity construction in Everyday Use. Dee's identification with the female image and her aestheticization of the reality and the history of African American reflect consumer culture acts as the "Other" in the Dee's identity construction. However, consumption culture also serves as the domain where Dee establishes her self-identity as a black female in a white-dominant world. Through the exploration of the double role of consumer culture in Dee's identity construction, this thesis advocates that in Every Use Walker presents the new black women dilemma in white-male consumer society and her thought on how to construct black female identities under the invasion of consumer culture into the American South, so that to some extent it makes certain contribution to the issue how women construct their own identity in the consumer society full of survival anxiety.

\section{Keywords}

Everyday Use, Dee's Identity Construction, Consumer Culture

\section{Introduction}

\subsection{The Research Significance}

Everyday Use, written by black female American writer Alice Walker, is an excellent short story published in 1973, some nine years before she won Pulitzer Prize for The Color Purple. Since it was published, this short story has gained great popularity. Many scholars have done many researches on this short story. As for the interpretation of theme, many critics focus on the writer's view on ethnical cultural identity and how to inherit the heritage. Many critics praise Mother and Maggie's loyalty to their ethnic identity and cultural heritage, but condemn Dee's betrayal of black cultural heritage. Some critics advocate the necessity and feasibility of fusion be- 
tween white and black cultures. As for the characters, some studies are done in light of the psychology and feminism. As for the artistic features of this short story, symbols and irony have gained the deep analysis from the perspective of formalism. Moreover, some research deals with narrative strategy from the perspective of feminist narratology or spatial narratology. Another research deals with this short story in light of the consumer culture. The aestheticization of everyday life is a cultural strategy adopted by the mainstream society to control rigorously the black community. However the studies on this story from this perspective are rarely available. As for the character Dee, the previous research presents Dee confronts dilemma of self identity in the multi-cultures for Dee knows a little about the past and loses her own identity in pursuit of the black people's independent culture. On the base of these studies, this paper tends to answer what role consumer culture plays in Dee's constructing her identity as a black female in American in the 1960s-1970s. The analysis will be made on the basis of related consumer culture theory in the following three aspects: the female images, the aesthetic concept and fashion implied in Everyday Use.

\subsection{The Research Background}

Generally speaking, consumer culture is "a social arrangement in which the buying and selling of goods and services is not only a predominant activity of everyday life but also an important arbiter of social organization, significance and meaning” (from wikipedia). Some scholars think that consumer culture refers to material activity and the accompanying psychological process, which influence the consumer's interests, tastes, thoughts and morality, even the consumer's daily consumptive behaviors and the way of life (Li \&Wang, 2012: p. 99). In this paper, consumer culture refers to a type of material culture, that is, a culture of the use or appropriation of objects or things. Consumer culture is a type of material culture in which the consumer emerges as a master category of collective and individual identity (Lury, 2011: p. 9).

Among various studies on consumer culture, there are three main perspectives on consumer culture: Marxism, semiotics, together with anthropology and sociology. The earliest research in consumer culture can date back to Karl Marx who put forward the notion of "commodity fetishism” and "alienation of labor". Based on the Marx's thought, later the neo-Marxist schools especially the Frandkfurt School have made significant research on the consumer culture. To study the cultural meaning of things many scholars turn to semiotics. Roland Barthes is the first person who introduces semiotics into the consumer culture in his Mythologies (1957). Jean Baudrillard (1929-2007), the French social theorist, contributes a lot in interpreting modern and post-modern consumer cultures in his The System of Objects (1968) and The Consumer Society (1970). In the study of consumer culture in light of anthropology and sociology, Pierre Bourdieu proposes theories of social stratification based on aesthetic taste in Distinction: A Social Critique of the Judgment of Taste.

In this paper, much attention will be paid to the consumer culture in 1960s-1970s in America South. The reason is that the exact historical setting of the story is not indicated, but a number of details point to a period covering part of 1960s-1970s in the American South. For example, the narrator mentions a television show and Johnny Carson, host of "Tonight Show" at the zenith of his career. American society has "shifted from a productive society to a consumer society in the late nineteenth century and the early twentieth century", (Jiang, 2004: p. 73) but consumer culture in the American South has been developing lower than the American north. Historically, the South relied heavily on agriculture with sharecropping and tenant farming as a dominant form, and was highly rural until after 1945. It has since become more industrialized and urban but the process of industrialization and urbanization in the South is quite lower than the North for the historical factors. The South has the highest percentage of African Americans in the country and in the 1960s-1970s the consumption culture expands its power to the rural area in America South.

\section{Dee's Female Identity and Female Image in Consumer Culture}

According to the Belgian sociolinguist Jan Blommaert, identity is who and what you are. He proposes that we can see identity as particular form of semiotic potential, organized in a repertoire which is conditioned by dynamics of access (Blommaert, 2005: p. 203). The gender researchers also point out the gender identity is the result of social construction. The feminist Simone De Beauvoir's statement can be strong evidence: “One is not born a woman, but becomes one” (Beauvoir, 1952: p. 295). Her analysis focuses on the Hegelian concept of the other. It is the social construction of Woman as the quintessential other that Beauvoir identifies as fundamental to women's oppression. This part will focus on female image of Dee in Everyday Use and her experience and try 
to explore the role of the consumer culture as the role of the Other in Dee's female identity construction.

\subsection{The Conflict of the Female Image in Mrs. Johnson and Dee}

At the beginning of the story, Mrs. Johnson deliberately chooses to wait for her daughter Dee's coming home in the yard. Mrs. Johnson, the narrator in Alice Walker's Everyday Use, lives in and feels comfortable with the Southern tradition of farming life. However, in the third and fourth paragraph of this short story, Mrs. Johnson dreams a dream in which Dee and she are suddenly brought together on a TV program hosted by Johnny Carson. Here we see the consumer culture in the urban has invaded into the comfortable country life for TV is an important media to spread the mass and consumer culture. In the TV programs the children who have made success embrace and express thanks for their parents. But the mother thinks that such kind of touching scene can never happen between herself and her daughter, The reason is that the image of Mrs. Johnson is far from the one required by Dee and the TV program.

In real life, the narrator is "a large, big-boned woman with rough, man-working hands", wears loose clothes such as flannel nightgowns and overalls and worked hard to make a living such as slaughtering mercilessly like a man, "breaking ice to get water for washing" in winter. She can eat "pork liver cooked over the open fire minutes after it comes steaming from the hog" (Guerin et al., 2004: p. 389). Here it depicts a typical image of African American woman living in the rural area of American South. Such kind of African-American women possess more masculine traits. From the narrator's description, we do not see any sign of self-depreciation but a sense of pride for her masculinity. There are two reasons for the narrator's perception of beauty and body. First, African-American women believe that African-American males prefer larger women, so they have no reason to lose weight and think their large figure more attractive. Another reason is that the age-old agrarian African American way of life requires lots of manual labor. Women have to do lots of things by their own hands so that women develop big figure to support their labor both on land and at home.

However the popular TV programs and Dee want her to be: a hundred pounds lighter, her shin like an uncooked barley pancake. Her hair glistens in the hot bright light and. Johnny Carson has much to do to keep with her quick witty tongue. The image of African American women required by the TV programs and Dee conforms to the standard of body size and beauty for the female required by the consumption culture especially by the dominant white culture. Such kind of women have a small and thin figure, a special taste for the clothing and hairstyle, and possess more feminine traits, which is quite different from image of African American woman living in the rural area of American South. African American women experience greater social mobility, they may be especially at risk, due to the exposure to white women preferences, attitudes, and ideals about beauty, weight, and food... Dee represents a small group of African-American women who identify more with the dominant culture than with their racial or ethnic culture.

The conflict of the female image in Mrs. Johnson and Dee in fact reflects the conflicts in cultures: the Southern tradition of farming life in rural area and the thriving consumer culture in the urban. At the same time there is an emerging consciousness that the African-American are not necessarily destined to subsistence living but to enjoy the advantage and convenience brought by technology and science.

\subsection{Dee's Identification with Female Image in Consumer Culture}

For African America women like Dee, consumer culture acts as the dual "Other” in gender and race. Unlike her mother, a typical image of black women, "a large, big-boned woman with rough, man-working hands” who construct herself to meet the gaze of African American males, Dee constructs herself like white woman on the basis of white man's preference for the small figured and thin female. Dee is subject to "male gaze" and becomes the object of white men's desires.

Her willingness to obey the standard of body and beauty established by the consumer culture will be discussed in the following two aspects: First, Dee, as a young girl, shares the same nature with the white woman that women cannot resist the allure of beautiful commodities. Such notion of womanhood has been discussed by Jennifer Jones. In his Coquettes and Grisettes, it is argued that “women's psychology and sensory apparatus made them ideally suited to consume, and their passivity rendered them particularly vulnerable to capture by their sensual delight in agreeable and frivolous objects” (Jones, 1996: p. 36). In Everyday Use, when Dee is a little girl, she likes nice things. She is so sensitive to the color that she has natural ability to dress herself in a suitable and new way without her mother's guidance. For example, she chose "a yellow organdy dress to wear 
to her graduation from high school; black pumps to match a green suit she'd made from an old suit... at sixteen she had a style of her own and know what style was” (Guerin et al., 2004: p. 390). As a young girl, she does get great pleasure in decorating herself with the colorful and nice things, so she is open and easily captured by the agreeable things. Second, her identification with the ideal female image of white man reflects her political aspiration. As a black girl in rural area of American South, she is lucky enough to get high education, which germinates her dream to change the lower and despised situation and to gain due recognition in the white-dominated society. However she cannot change her skin color and birthplace. Maybe her mother has shared the same dream a dream which she think impossible to realize. Dee thinks marriage acts as a short cut to improve herself from lower position in marginalized minorities to the middle-upper class in the mainstream society. So she builds herself in the manner, language to meet the desired image by the white man. She succeeds in attracting the young and furtive boys: "Impressed with her they worshiped the well-tuned phrase, the cute shape, the scalding humor that erupted like bubbled in lye”. When she established herself as an ideal figure in white man's eyes, she is brave enough to court Jimmy T. and "turn all her faultfinding power on him". But Jimmy T. does not accept her love and marry "a cheap city girl from a family of ignorant flashy people”. Her failure in pursuing a white boy to some extent shatters her dream to integrate herself into the white society by construct herself on the standard of beauty and body advocated by the dominant middle class culture.

\section{Dee's Racial Identity and Aesthetic Perception in Consumer Culture}

Consumer culture plays an important role not only in Dee's construct herself as the ideal female in the gaze of white man, but also in Dee's aesthetic perception. Under the influence of consumer culture, she perceives these everyday common things and the house in an aesthetic way. She constructed herself as a collector with an elegant taste and a recorder of the African America history. There are two ways for Dee to collect things: one is that Dee owns the common everyday objects as decoration in her house; the other is that Dee can collect the visual images of her family with the help of Polaroid. This part will explore how consumer culture influences Dee's aesthetic perception especially her perception on the suffering past and the survival reality of the black American and the role of consumer culture in constructing her racial identity.

\subsection{The Conflict of Perception of Things in Mrs. Johnson and Dee}

Jean Baudrillard thinks that there are four ways of an object obtaining value: the functional value of an object; the exchange value of an object; the symbolic value of an object; the sign value of an object. The sign value proposed by the Baudrillard is an important complement to the Marxist theory of the value of goods. In this short story, Mrs. Johnson and Maggie focus on the functional value and the symbolic value in the conventional things. Mama and Maggie are not only the users of these things but also heritor of these things, because they know how to use them in daily life and the historical and cultural meaning behind these conventional things. While Dee pays more attention to the sign value in these things. The function of common everyday objects collected by Dee is to highlight her improvement in social status from a lower black female to a member of middle class with elegant taste.

Take the old quilts for example, for Maggie and Mama, the old quilts can be put into everyday day to keep warm in functional value aspect; the symbolic value of the old quilts lies in that two old quilts can be regard as a token of a family's history of pride and struggle, and of the African American historical and cultural heritage in American. In Dee's eyes, for the exchange value, the old quilts are priceless for its rarity. Dee lives in the urban where many things belong to the mass production. Even her mother in country has the quilts stitched by the machine rather by the hands in their house. So the old quilts are rare and unique both in the Dee's world and Mother's world. More attention will be paid on the sign value rather than the other value of the old quilts. The only thing that Dee could do with quilts is not to use them but to hang them on the wall. The sign value of the old quilts lies in that it can serve as a decoration to display her taste as black women who has become a member of middle class.

The conflict of perception of things between Mrs. Johnson and Dee in fact reflects their different social status of the black woman and different attitudes towards the suffering history of the black American: Maggie and Mama who have a lower social status has a better understanding of their own history in America, while Dee who improves herself form a lower position to a middle class only sees the oppressive side of history imposed by the white and wants to break with the past of the social, psychological hardship. 


\subsection{Dee's Identification with Aesthetic Perception in Consumer Culture}

In the process of Dee's constructing herself as a desired female by white man, aesthetic perception in consumer culture also acts as the "Other" in her constructing her racial identity. The French sociologist Pierre Bourdieu in Distinction: A Social Critique of the Judgment of Taste points out that the elite in society define the aesthetic values like taste and the different levels of the exposure to these aesthetic values can results in the social stratification. In Dee constructing herself as a collector with an elegant taste, she loses her racial identity for she does not understand historical and cultural meaning embodied by the conventional things and the function of common everyday objects collected by Dee is to highlight her improvement in social status from a lower black female to a member of middle class with elegant taste. She becomes the other of her mother and sister who stick to their racial culture. The influence of aesthetic perception in consumer culture on her constructing her racial identity will be discussed in the following two aspects.

Firstly, Dee constructs herself as a collector by owning the common everyday objects to decorate her house. What Dee collects is common everyday objects rather than the things in museum or works of art in exhibition reflects not only the effacement of the boundary between art and everyday life in modern consumer culture but also Dee's aestheticization of the harsh reality of the black female in American South. In Consumer Culture and Postmodernism, Mike Featherstone has pointed out that the inherent meaning of the aesthetic in consumer age refers to the aestheticization of everyday life. One meaning of the aestheticization of everyday life is that art can be anywhere or anything. The detritus of mass culture, the debased consumer commodities, could be art (Featherstone, 2000: pp. 95-96). When Dee enters in the house, she was attracted by those conventional items found in the house such as the quilts, the benches used in place of chairs, the churn, and the dasher. Everything in the house delights her for she thinks of the artistic value in them. For example, she wants to use the churn top as a centerpiece for the alcove table. All these common things in the house everyday life have become a kind of art in Dee's eye. However, the conventional items such as the quilts, the benches used in place of chairs, the churn, the snuff in the shabby house represent the lower economic situation of rural blacks and social status. To some extent, her effacement of the boundary between art and everyday life reflects her aestheticization of the harsh reality of the black female in American South.

Secondly, Dee constructs herself as a recorder of the African America history by collecting the visual images of the traditional house with the help of Modern Polaroid. When she returns home, she is eager to "line up picture after picture" that shows her mother in the front of the house. She carefully manages to get her mother, Maggie, house and the nibbling cow all in the same shot. The narrator tells us that "she never takes a shot without making sure the house is included”. Here Dee's action of taking photos of the house is meaningful in consumer culture. Mike Featherstone has argued that another sense of the aestheticization of everyday life refers to the rapid flow of signs and images which saturate the fabric of everyday life (98). In Dee's eyes, the existence of the house as a preserver and protector of the age-old African American way of life is not a living thing but a series of images and pictures. Another meaning of Dee's action is that Dee turns the suffering history of African American represented by the house into a visual image. Jean Baudrillard points out that the modern culture built on the advanced media means supported by high technology is endowed with a new property-simulacra. The sign and simulacra are widely spread by the science and technology, as result, art and aesthetic are expanded drastically from the traditional art into every corner of society, which effaces the image and the reality. In this short story, the narrator tells us that Dee once hated the old house and wanted to tear the reconstructed house down, for she does not face their oppressive history imposed by the white man. To the mother's surprise, Dee takes pictures of the house and do not show her dislike. Dee takes advantage of the Polariod to visualize the suffering history into "simulacra" where the time is fixed. She perceives the house not in the reality bur in its image. Therefore, the image of the house not only relives Dee' shameful and painful feeling of African America history but also adds some poetic color to their history.

In Dee constructing herself as a collector with an elegant taste, the aesthetic perception consumer culture acts as the other in Dee's constructing her racial identity, for such aesthetic perception results in Dee's aestheticization of the reality and the history of African American. On the one hand, she constructed herself as a collector with an elegant taste to display her social status as one member of the middle-upper class in the mainstream society and her aestheticization of the harsh reality of the black female in American South. One the other hand, Dee constructs herself as a recorder of the African America history with the modern Polaroid who is enchanted by the image rather than the real history. 


\section{Fashion and Dee's Identity}

In the former part, consumption culture acts as the "Other" in the Dee's identity construction through the female image and the aesthetic concept. However, consumption culture also serves as the domain where Dee establishes her self-identity as a black female in a white-dominant world. French scholar Michel de Certeau in The Practice of Everyday Life points out that despite repressive aspects of consumer culture, the consumer can reverse the function of the available source and materials to satisfy their own needs in practice, posing a challenge to the established order of society. In Dee's constructing her identity, there exists some creative resistance to the repressive power of the consumer culture. The subject construction of Dee will be discussed from the African fashion and car as a form of space in the context of consumer culture.

\subsection{African Fashion and Dee's Identity}

Fashion as an important part of the consumer culture plays an important role in Dee's constructing her identity. Before this, our attention will be paid to the social motive and function of fashion. German sociologist Georg Simmel in The Philosophy of Fashion argues that fashion is a form of a social relationship. On the one hand, fashion allows someone to conform to the standard of a group so as to make the members of certain group more intimate. On the other hand, fashion can be used by certain group to distinct itself from other groups. In other words, fashion allows some to be unique and special by deviating from the norm. For an individual, fashion can satisfy one's desire both to belong to a group and to be individual. In this story, Dee lives in the United States 1960s-1970s. At that time, there is a political movement called "Black Power" expressing a new racial consciousness among blacks. Under the slogan of "Black is beautiful”, many black women and men use their special clothing style and other decorations to establish a collective identity. The African fashion was used to express the political desire of Africa Americans at that time. Therefore, when Dee imitates African fashion established by Africa Americans, Dee gains a sense of belonging which makes her feel not lonely on the process of seeking her identity as a black female in America and a sense of security which relives her responsibility and guiltiness for her different appearance, taste and manner in white-dominant society. However, what is more important for Dee is that African fashion can serve as an outlet to satisfy her desire to be herself as a black female. In the part two and three, Dee's struggles to construct her identity as an ideal female on the standard of white man and a collector with the same elegant taste as a member of middle class does not make herself different from the white people. Therefore, fashion can be an alternative way to express Dee's desire for self-identity unrealized in mainstream society.

In following African fashion in 1960s-1970s, Dee is creating a new image of black women. Such kind of black women do not construct themselves on the standard of beauty, body size, taste advocated by the dominant middle class culture as the gazed object of the white man. In contrary, new black women manage to construct themselves on their ethical culture. Names, the use of words, clothing and decorations can be regarded as different ways of creating identity. In this story, Dee replaces her earlier name with "Wangero”. For Dee, her earlier name represents the oppressive culture of the dominant majority, so she gives it up and chooses an African pattern to display the transformation of her identity. In language, Dee greets her mother with an African dialect salutation "Wa-su-zo-Tean-o". In clothing and decoration, she wears an impressively long and bright dress, with her hair "straight up like the wool on a sheep", earrings gold "hanging down to her shoulders", bracelet "dangling and making noise when she moves her arm” (Guerin et al., 2004: pp. 389-390). From the names, the use of words, clothing and decorations, we can see Dee is constructing a perfect example of the black women who turns their eyes on Africa to create fashion to construct their own identity. The uniqueness of African fashion lies in that it is hard to be imitated by the white people for example, African hairstyle, so that we can say that African fashion highlights the distinctive difference between African American and the white people and that African fashion to some extent can be used to make Dee’s identity as an African American more stable.

\subsection{Car as a Form of Space and Dee's Identity}

Car is undoubtedly one of the most important goods which represent consumer culture in America in twentieth century. In this story, the first appearance of Dee in this short story is that she comes out of the car and the last scene is that Dee and her friends drive a car away while Maggie and her mother watch the car dust settle. Here the car is not only a moving and fashionable vehicle but also a form of space which displays the culture Dee be- 
longs. If the house and the garden are the space Maggie and the mother belongs to, car can be regarded as the space which Dee belongs to in this story. French philosopher Henri Lefebvre in The Production of Space says "(Social ) space is a (social) product... the space thus produced also serves as a tool of thought and of action... in addition to being means of production it is also a means of control, and hence of domination, of power" (Lefebvre, 1991: p. 158). Every society produces a certain space. Space does have its own cultural and ideological meanings in certain society. So their difference of belonging spaces reflects their different economic conditions, cultures and social status. What role the car as a form of space plays in the process of Dee's construction of her identity will be discussed in two ways: comparison with Dee's space and Maggie and their mother's space and the position of the car in female's consumption.

First, comparison with Dee's space and Maggie and their mother's space will be made to show the role of car in Dee's construction of self identity. The house and the garden represent simple traditional agrarian life. Maggie and mother are strictly confined to their house. Their identity is basically defined as mothers and wifes who are supported to their nurturing gifts and exert their influence on their children and husbands. They are living in simple and poor living conditions at the bottom of society. While the car serve as the representative of a complex and turbulent consumer culture in modern life. Unlike Maggie and mother confined themselves in their house in a small country, many new black women like Dee make best use of car to get rid of the constraint of their narrow domestic sphere and to get freedom to go where they want according to their plans. Compared with Mother and Maggie, Dee has the chance to define herself in public space because the car makes it easier for her to go the public space and it also reflects Dee's wealthy economic conditions and Dee's consuming power.

Another perspective is from the position of the car in female consumption. The study done by Emily S. Rosenberg shows that when the car initially occurred, the female was regarded unsuitable for driving because of emotional personality and fragile constitution. However in the late 1920s Dee represents a small group of African-American women who identify more with the dominant culture than with their racial or ethnic culture. When the car entered into the overproduction, the car companies changed marketing strategies and began to advocate that the female is portrayed as the suitable driver of the car. Under the influence of the mass media especially the advertising, the female is considered as the potential buyer and driver of a car. As a result, the car is no longer goods exclusive to men but an object endowed with rich cultural meaning. The car becomes a symbol of independence and freedom of woman.

\section{Black Female Dilemma in White-Male Dominant Society}

In the earlier 20th century, the shift from an agrarian to an industrial-commercial society took place in American society. At that time because of mass production, the new technology of and the development of the mass media, American society has "shifted from a productive society to a consumer society". For Black Americans, the shift had occurred at a markedly slower pace. However, in the 1960s-1970s the consumption culture expands its power to the rural area in America South. Many black females like Dee and Maggie seem unwilling to participate in that shift. While, some new black women like Dee is longing for it.

In the process of Dee constructing her identity as a black woman in white-dominant society, consumer culture acts as the double role. In fact, the double role of consumer culture reflects the new black female dilemma in white-male dominant society. On one hand, under the influence of consumer culture, Dee identifies herself with the female image in the gaze of white man and deals with the harsh social reality and the suffering history of Black American in an aesthetic way. Dee represents a small group of African-American women who may lose themselves for they identify more with the dominant culture than with their racial or ethnic culture when they struggle to establish themselves in white-dominant society in American in 1960s-1970s. On the other hand, under the influence of fashion, an important part of consumption culture, which shows itself in name, language, clothing, hairstyle and car, Dee establishes her self-identity as a black female in a white-dominant world for she began to identify her ethnic culture. Compared with her mother and sister who are confined in the house, Dee represents a kind of new black women who say goodbye to their traditional role as stay-at-home mother and wife and trying to redefine themselves in family and society.

Here for the character Dee, Alice Walker shows her worries about how some new black women construct their self identities without losing their own ethnic culture in white-male consumer society. For the mother and Maggie, should they stick to the simple and self-productive agrarian life regardless of the changes of time? Should they stay at home and play their traditional role as mother and wife? The author also implies her thought 
on how to construct black female identity under the invasion of consumer culture into the American South.

\section{Conclusion}

Through the exploration of the double role of consumer culture in female image, aesthetics and fashion in Dee's identity construction, this thesis advocates that in Every Use Walker presents the new black women dilemma in white-male consumer society and her thought on how to construct black female identity under the invasion of consumer culture into the American South. Hopefully this paper to some extent will make certain contribution to the issue how women construct their own identity in the consumer society full of survival anxiety.

\section{References}

http://encyclopediajrank.org/articles/pages/6480/Consumer-Culture.html

Li, C. L., \& Wang, X. M. (2012). An Analysis of the Consumerism in William Faulkner's Works. Foreign Literature Studies, $04,99$.

Lury, C (2011). Consumer Culture (2nd ed.). Cambridge: Polity Press.

Jiang, D. C. (2004). Consumer Culture, Identity Construction and Modernism—-The Evolvement of the American Consumer Culture in the 20th Century. Foreign Languages Research, 2, 73.

Blommaert, J. (2005). Discourse: A Critical Introduction. Cambridge: Cambridge University Press. http://dx.doi.org/10.1017/CBO9780511610295

Beauvoir, S. D. (1952). The Second Sex (Translated by Parshley, H. M.). New York, NY: Random House.

Guerin, W. L., Labor, E., Morgan, L., \&Reesman, J. C. (2004). A Handbook of Critical Approaches to Literature (4th ed.). Beijing: Foreign Language Teaching and Research Oxford: Oxford UP.

Jones, J. (1996). Coquettes and Grisettes Women Buying and Selling in Ancient Régime Paris. In V. de Grazia, \& E. Furlough (Eds.), The Sex of Things Gender and Consumption in Historical Perspective (p. 36), Berkeley: University of California Press.

Featherstone, M. (2000). Consumer Culture and Postmodernism (Translated by Liu, J. M.). Nanjing: Yilin Press.

Lefebvre, H. (1991). The Production of Space (Translated by Nicholson-Smith, D.). Malden, MA: Blackwell Publishers Inc. 
Scientific Research Publishing (SCIRP) is one of the largest Open Access journal publishers. It is currently publishing more than 200 open access, online, peer-reviewed journals covering a wide range of academic disciplines. SCIRP serves the worldwide academic communities and contributes to the progress and application of science with its publication.

Other selected journals from SCIRP are listed as below. Submit your manuscript to us via either submit@scirp.org or Online Submission Portal.
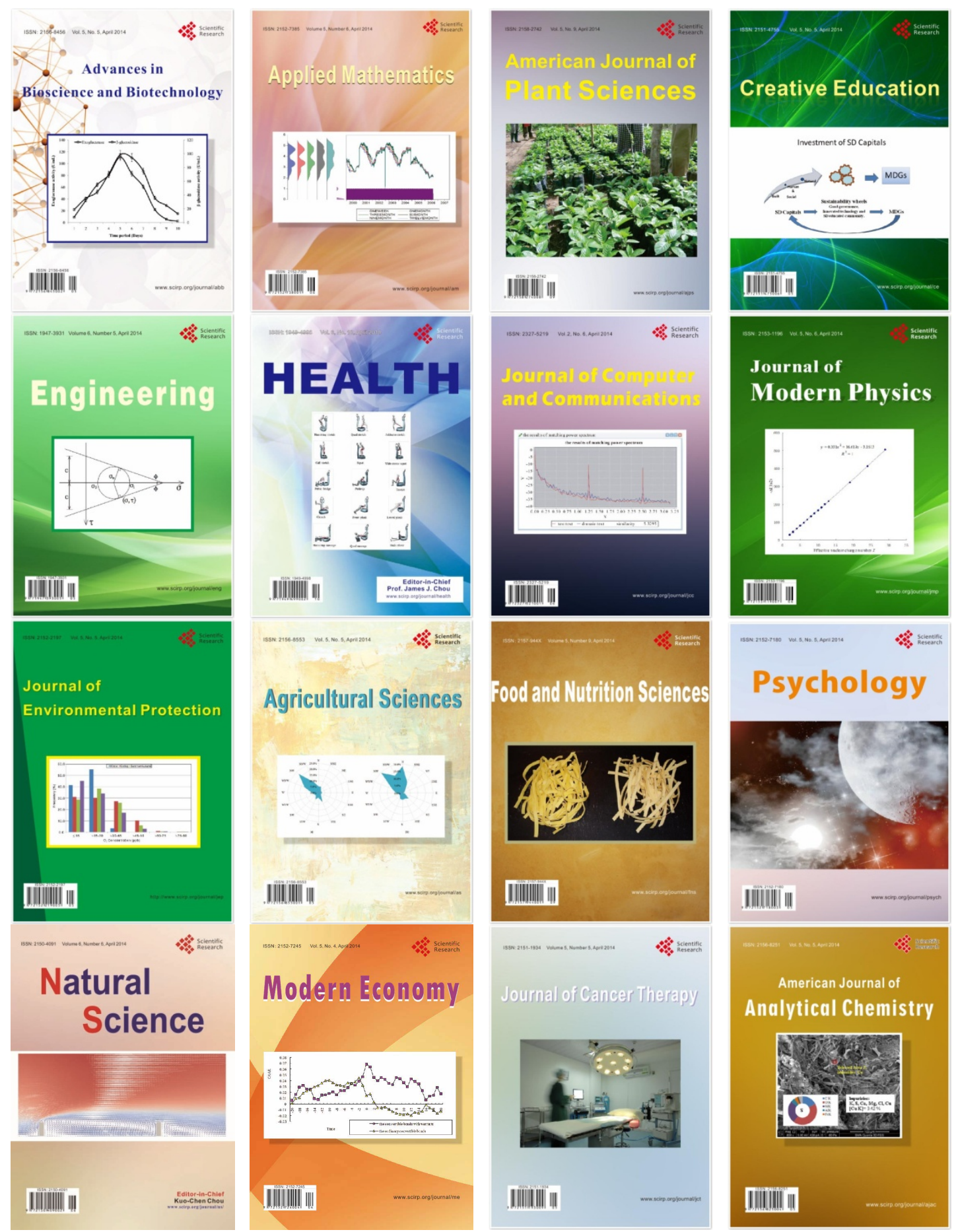